DR. BARBARA B. FLYNN (Orcid ID : 0000-0001-6577-5315)

Received Date : 24-Jan-2017

Accepted Date : 31-Jan-2017

Article type : Original Article

\title{
Supply Chain Power Configurations and their Relationship with Performance
}

\author{
Baofeng Huo, Barbara B. Flynn, Xiande Zhao
}

Article information:

Baofeng Huo, Barbara B. Flynn, Xiande Zhao (2017), "Supply Chain Power Configurations and their Relationship with Performance” Journal of Supply Chain Management, Vol. 53, No. 2.

\begin{abstract}
In order to lay the foundation for the study of supply chain power, we study power configurations at the level of interlocking power dyads (IPDs), viewing the simultaneous effect of upstream and downstream power. We build on four key constructs: dependence asymmetry (resource dependence theory), joint dependence (embeddedness perspective), power type differential (based on French and Raven, 1959) and power source asymmetry. We examine the research question of what the relationship is between IPDs and the focal firm's operational performance, developing hypotheses based on the dependence asymmetry, joint dependence, power type differential and power source asymmetry of theoretical IPDs. A survey of over 600 respondents in China was used to collect data on focal firm perceptions of upstream and downstream power, with cluster analysis yielding eight IPDs. Inferential analysis revealed the importance of joint dependence, dependence asymmetry, power type differential and power source asymmetry to the operational performance of the focal firm.
\end{abstract}

\section{INTRODUCTION}

Nearly all men can stand adversity, but if you want to test a man's character, give him powerAbraham Lincoln

The measure of a man is what he does with power - Plato

This is the author's manuscript of the article published in final edited form as:

Huo, B., Flynn, B. B., \& Zhao, X. (2017). Supply Chain Power Configurations and their Relationship with

Performance. Journal of Supply Chain Management. http://dx.doi.org/10.1111/jscm.12139 
What is the role of power in a supply chain? Although power between individuals has been the topic of study for centuries, power relationships also exist between firms in a supply chain: "Power is at the heart of all business-to-business relationships (Cox, 2001, p. 10)." The question, then, is which firms benefit from supply chain power.

The traditional interorganizational perspective builds upon resource dependence theory (RDT) (Pfeffer \& Salancik, 1978). Because it views a firm as dependent on its external environment for resources to ensure its survival, RDT views power as control over valued resources. A supply chain member is vulnerable to the extent that it depends on other firms for resources that are important to its outcomes. Because of this dependence asymmetry, RDT assumes that the more powerful firm activates its power to serve its own interests, to the detriment of the other firm. In contrast, the embeddedness perspective (Granovetter, 1985) focuses on the total amount of power in a relationship, regardless of the symmetry with which it is distributed. Even in the presence of dependence asymmetry, joint dependence has been associated with positive outcomes for both firms because they recognize the importance of cooperating in order to mutually benefit (Ireland \& Webb, 2007).

This seeming paradox can be resolved by considering several additional factors relevant to supply chain power. First, a firm is subject to power from other firms in both its upstream and downstream supply chain. If it faces power with detrimental implications from one direction, there may be compensating beneficial effects of power from the other direction. Thus, it is important to consider source power asymmetry. Second, power is not a unidimensional construct; there is the possibility that different types of power may counterbalance each other. We propose that different types of supply chain power exist simultaneously in configurations, based on the seminal work of French and Raven (1959), which suggests that passive power types 
have a beneficial effect, while activated power types are more manipulative and can have a detrimental effect.

Therefore, our research question is: What is the relationship between upstream and downstream power configurations and operational performance? We synthesize the RDT and embeddedness perspectives by constructing interlocking power dyads (IPDs) to tease out key characteristics of supply chain power, including the effect of activated vs. passive power types and positive vs. negative power types on the operational performance of the focal firm.

We begin by examining the dependence asymmetry perspective described by RDT. We then develop the embeddedness perspective, focusing on joint dependence. To these, we add power type differential, based on French and Raven (1959), and power source asymmetry. Building upon dependence asymmetry, joint dependence, power type differential and power source asymmetry, we develop hypotheses about the relationship between theoretical IPDs and operational performance of the focal firm. Cluster analysis is used to identify IPDs that exist in a set of survey data from 617 Chinese manufacturers, and their relationship to the focal firm's operational performance is tested using ANOVA.

This research contributes to the literature on supply chain power by establishing IPDs that simultaneously consider dependence asymmetry, joint dependence, power type differential and power source asymmetry. It serves as a first step towards identifying a firm's supply chain power position and provides a building block for beginning to understand the role of power in a complex supply network.

This article is protected by copyright. All rights reserved. 


\section{POWER IN SUPPLY CHAINS}

\section{The Power Construct}

Power, which is the ability to influence the behavior of another (He, et al., 2013; Drea, et al., 1993), is the foundation of relationships between people or firms (Dapiran \& Hogarth-Scott, 2003), including firms in a supply chain. It can be intentionally activated or have an effect simply because of the knowledge that it exists (Ireland \& Webb, 2007). For example, Firm A may be proud to be a supplier to Firm B, which is large and very well known. A's decisions are influenced by B, even though B does not intentionally activate its power. Thus, power is a perceptual construct (Fiol, et al., 2001) that exists in the eyes of the firm that is influenced.

Prior supply chain power research is primarily at the level of dyads. A dyad is a pair of nodes and the link that connects them (Choi \& Wu, 2009), serving as a building block that provides a simplified relationship for study (Benton \& Maloni, 2005). Understanding power in supply chain dyads is a first step towards understanding it in complex supply networks, comprised of linked dyads that may be governed by different power relationships (Watson, 2001). For example, Bastl, et al (2013) describe coalitions that form when a weaker supply chain member aligns with another to form a triad. We extend dyadic analysis to interlocking power dyads (IPDs)s, examining a focal firm's perception of how it is simultaneously influenced by upstream and downstream dyads.

\section{Two Approaches to Understanding Supply Chain Power}

The bulk of the power literature is based on the perspective of resource dependence theory (RDT) (Pfeffer \& Salancik, 1978), which describes power as dependence asymmetry, intentionally activated, with negative implications. This literature focuses on how a firm can

This article is protected by copyright. All rights reserved. 
benefit from being in a position of power (Gulati \& Sytch, 2007) and how a less powerful firm can restructure its dependence (Casciaro \& Piskorski, 2005).

In contrast, the embeddedness perspective (Granovetter, 1985) describes power from the perspective of joint dependence, which is the total amount of power in a relationship, regardless of its distribution. According to this perspective, firms willingly cooperate because of a relationship's mutual benefits, and there is a mix of activated and passive power, with positive implications for both firms. This literature focuses on how firms can increase their level of joint dependence, while simultaneously managing the uncertainty associated with their dependence asymmetry (Yan \& Nair, 2016). These approaches provide two different perspectives of the way supply chain power is related to operational performance (Figure 1), described below.

\section{Insert Figure 1 About Here}

RDT Perspective. Resource Dependence Theory (Pfeffer \& Salancik, 1978) casts power as dependency asymmetry (Casciaro \& Piskorski, 2005; Hofer, 2015). Firm A's dependence on B is proportional to A's need for resources that B can provide and inversely proportional to the availability of alternative sources for them. If the net result is negative, A has a dependence advantage (power) (Emerson, 1962). On the other hand, if the net result is positive, A has a dependence disadvantage (Hofer, 2015). Thus, dependence asymmetry is the difference in power between firms in a dyadic relationship.

A firm increases control to the extent that it furnishes resources that are more critical and scarce (Pfeffer \& Salancik, 1978); thus, RDT views power as control of valued resources. Strategies used by a dependence advantaged firm include adversarial tactics (Gassenheimer \& Ramsey, 1994), requiring transaction-specific investments (Jap \& Ganeson, 2000), dictating relationship terms (Casciaro \& Piskorski, 2005) and exerting power during negotiations (Crook

This article is protected by copyright. All rights reserved. 
$\&$ Combs, 2007). From the perspective of the dependence disadvantaged firm, compliance represents loss of discretion (Pfeffer \& Salancik, 1978), as it accedes to the wishes of the other firm (Touboulic, et al., 2014). To compensate for this, RDT prescribes restructuring dependence through uncertainty reduction or seeking more stable access to resources (Casciaro \& Piskorski, 2005). Thus, RDT assumes that power is intentionally activated to influence another firm (Pfeffer, 1997). Further, it assumes that power activation has negative implications for the other firm.

Dependence asymmetry is associated with instrumental relationship commitment, based on compliance with extrinsic rewards or punishment (Brown, et al., 1995; Zhao, et al., 2008). Each firm instrumentally calculates the costs and benefits of participating in a relationship, viewing it as severable if its costs outweigh the benefits. In a supply chain, upstream and downstream power may influence a firm differently; thus, it is important to consider dependence asymmetry in terms of its source. Therefore, we consider dependence asymmetry (difference between customer or supplier power and focal firm power) and source asymmetry (difference between customer and supplier power) as separate dimensions of supply chain power.

Embeddedness Perspective. Emerson's (1962) foundation for the study of power described a second dimension, in addition to dependence asymmetry. Joint dependence is the sum of dyadic firms' dependence, independent of dependence asymmetry. This perspective reflects March's (1966) force depletion model, which views a relationship as having a fixed stock of power. Joint dependence, then, is the total stock of power in a relationship, while dependence asymmetry is its allocation between firms. An asymmetric dependence relationship can be characterized by varying levels of joint dependence and vice versa, thus, both dimensions should be considered simultaneously (Hofer, 2015). Emerson (1962) illustrates this with the example of a pair of

This article is protected by copyright. All rights reserved. 
criminals on the run versus casual acquaintances. Each relationship could fall anywhere on a continuum between symmetric and asymmetric dependence; however, joint dependence is much higher for the criminals, whose escape depends on their ability to work together.

The logic of embeddedness (Granovetter, 1985) describes the symbiotic coexistence (Dyer, 2000) of joint dependence. Knowledge that the relationship will continue causes the firms to be more willing to work together (Hofer, 2015), even though one may hold a dependence advantage. Through their interaction, the firms become better acquainted (Nielson, 1996); as the positive actions of one firm are reciprocated, both come to perceive the relationship as rewarding (Hofer, 2015). Through this process, the firms develop cooperative norms that help govern the relationship (Hofer, 2015; Cai \& Young, 2008) and function as "moral controls" against opportunism (Joshi \& Campbell, 2003).

Joint dependence is associated with normative relationship commitment, which is willingness to secure and maintain a relationship, based on identification and internalization of common norms and values (Brown, et al., 1995; Morgan \& Hunt, 1994; Wetzels, et al., 1998; Zhao, et al., 2008). It is associated with long-term orientation, effective conflict resolution and willingness to forego immediate self-interest for the benefit of the relationship (Gulati \& Sytch, 2007). It results in increased levels of joint action, fine-grained information exchange and trust (Gulati \& Sytch, 2007), described below, which serve as valuable resources for both firms.

Joint action is manifest in activities related to product design, cost control, quality improvement and bilateral development of solutions. Through joint action (Zaheer \& Venkatraman, 1995), firms develop shared understanding of the usefulness of mutually beneficial behavior (Lawler, et al., 2000). Joint action increases identification between firms (Mizruchi, 1989), as each focuses on the other's responses and attitude, which leads to empathy

This article is protected by copyright. All rights reserved. 
and internalization of each other's values (Gulati \& Sytch, 2007), structural and attitudinal convergence (DiMaggio \& Powell, 1983) and consonance through joint language and shared emotions (Czinkota, et al., 2014). Consonance leads to resonance, through a "relational evolution," through which firms create opportunities to achieve common goals (Czinkota, et al., 2014).

Fine-grained information exchange about customer demand, sales forecasts, order status, inventory levels, capacity availability, lead times, quality and other topics is important to joint action (Gulati \& Sytch, 2007). As both firms recognize its benefits, the incentive to share information increases, making firms less inclined to withhold information for their own use (Provan, 1993), and facilitating the efficiency of information exchange (Di Maggio \& Powell, 1983). Joint dependence facilitates distribution of information to the firms where it will have the best outcomes (Huber, 2001), providing strategic benefits. Thus, fine-grained information exchange channels the vision, strategies and practices of both firms into the same direction (Hult, et al., 2004).

Trust is the expectation that a firm can be relied upon to fulfill obligations, behave predictably and act fairly, even if the temptation for opportunism is present (Zaheer, et al., 1995). It induces reciprocal acts of trust, fostering greater mutual trust, reducing the need for other safeguards and supporting deeper joint action and fine-grained information exchange. In this way, joint action, fine-grained information exchange and trust provide resources that benefit both firms.

\section{Power Types}

In addition to dependence asymmetry, power source asymmetry and joint dependence, we propose that the configuration of power types is important in supply chain power 
relationships. While some firms display overall unity of several types of power, others focus on specialized types of power (March, 1966). We employ French and Raven's (1959) seminal typology to describe different types of power, summarized in Table 1, then describe how they function within configurations.

\section{Insert Table 1 Approximately Here}

Power types can be grouped by their need for activation. Activated power types are characterized by conscious, intentional use (Pfeffer, 1997; March, 1966), to support a desired outcome. They provide resources for a dependence disadvantaged firm, on the condition that it does as the more powerful firm wishes (Ke et al., 2009); thus they capitalize on dependency asymmetry. There are two types of activated power. Reward power is provision of a positive outcome, in exchange for desired behavior. Coercive power is the willingness to inflict negative consequences for non-compliance (Kumar, et al., 1995; Gundlach \& Cadotte, 1994).

In contrast, passive power is possessed, rather than intentionally activated (Ke, et al., 2009; Brown, et al., 1995). It is based on a firm's perceptions of another firm's power; thus, it is perceived as intrinsic to the other firm. There are three types of passive power. Expert power results from attribution of expertise to another firm (Branyi \& Jozsa, 2015). Although information power is sometimes included as a type of passive power, the difference between expert power and information power is subtle (Ke, et al., 2009). Referent power comes from the desire to identify with and be similar to a highly esteemed firm (Frost \& Stahelski, 1988; Raven, et al., 1998; Czinkota, et al., 2014). Legitimate power stems from the internalized value that a firm is obligated to accept another firm's influence (Pfeffer, 1997; Sullivan \& O'Connor, 1985).

These types of power exist within a configuration, potentially supporting or counterbalancing each other. We propose that power type differential (difference between the 
strongest and weakest type of power in a configuration), should be considered in the study of supply chain power, in addition to joint dependence, dependence asymmetry and power source asymmetry.

\section{HYPOTHESES}

We developed interlocking power dyads (IPDs), to help examine power relationships in a complex supply network. An IPD consists of an upstream dyad and a downstream dyad, with a focal firm at the intersection point. Figure 2 describes IPD archetypes in terms of their dependence asymmetry, joint dependence and power type differential. Because a focal firm's upstream and downstream dyads are not necessarily mirror images, we also included power source differential. We do not expect that all theoretical IPD archetypes will exist within a specific set of data, since there is a large number possible.

\section{Insert Table 2 Approximately Here}

We begin by examining dependence asymmetry and joint dependence, holding power type differential and power source asymmetry constant, and their relationship to the focal firm's operational performance. RDT suggests that dependence asymmetry is inversely related to the focal firm's operational performance, due to the more powerful firm's control of resources needed by the focal firm; the focal firm's operational performance suffers when it must act in the interests of the more powerful firm, rather than its own. For example, the focal firm may be forced to comply with non-optimal lot sizing and scheduling decisions or function without information resources that are important to its operations. Although these decisions benefit the more powerful firm, they are detrimental to the focal firm's operational performance. Because of dependence asymmetry, neither firm has an incentive for joint action, since each seeks to protect its own resources. Similarly, fine-grained information exchange will be low; the more powerful

This article is protected by copyright. All rights reserved. 
firm will share only what it believes is necessary to the advancement of its own interests, while the focal firm fears that any information that it provides may be used against its interests. As the focal firm sees its operational performance deteriorate through association with the more powerful firm, trust is reduced. Thus, the more powerful firm's control of critical resources is detrimental to the focal firm's operational performance.

However, joint dependence is expected to be positively related to the focal firm's operational performance; dyadic firms benefit by working together, just as criminals on the run do in Emerson's (1962) example. Their symbiotic coexistence (Dyer, 2000) is underscored by knowledge that withholding important resources could jeopardize both firms' performance (Lusch \& Brown, 1982), casting the "shadow of the future" (Heide \& Miner, 1992) on their actions. High joint dependence is positively related to joint action and fine-grained information exchange, as both firms develop cooperative norms (Hofer, 2015), increase identification with each other (Brown,et al., 1995), develop bilateral solutions to operational problems (Zaheer \& Venkatraman, 1995) and exchange detailed information about operational decisions (Gulati \& Sytch, 2007; Hult, et al., 2004). Trust develops as each firm demonstrates that it is honest, reliable and stands by its word (Yu \& Liao, 2008), helping the focal firm improve its processes through compliance with beneficial upstream and downstream influences.

We describe the archetype with high dependence asymmetry and joint dependence, combined with low power type differential and source asymmetry, as a strong across-the-board IPD (see Table 2). High joint dependence functions as a moral control against opportunism (Joshi \& Campbell, 2003), due to recognition that withholding valuable resources can jeopardize both firms' performance (Lusch \& Brown, 1982). Thus, upstream and downstream beneficence is ensured by high joint dependence, despite high dependence asymmetry. This is exhibited in

This article is protected by copyright. All rights reserved. 
joint problem solving, sharing process information and knowledge, and cooperative operational decision making, which are positively associated with the focal firm's operational performance. This leads to our first hypothesis:

H1a: Strong across-the-board power IPDs are more strongly related to the focal firm's operational performance than moderate or weak across-the-board power IPDs.

In the moderate across-the-board IPD, joint dependence and dependence asymmetry are at a medium level, as are all of the power types. There is less joint action and fine-grained information exchange than in the strong across-the-board IPD, with a correspondingly smaller impact on operational performance. The operational benefits are similar to the strong across-theboard IPD, but at a somewhat lower level. In the weak across-the-board IPD, dependence asymmetry and joint dependence are at the lowest levels of all IPDs; neither the customer, supplier nor focal firm have much power, thus, we expect a weak relationship between this archetype and the focal firm's operational performance. Thus,

H1b: Moderate across-the-board power IPDs are more strongly related to the focal firm's operational performance than weak across the board power IPDs.

The role of power type differential is illustrated through archetypes related to power activation and power valence. While some power types constrain the focal firm's operating decisions through withholding important resources, other types have a counterbalancing effect, supporting the focal firm's operational decisions. Power activation reflects "...whether the source does or does not control the reinforcement which guides the target's behavior (Tedeschi, et al., 1972, p. 292)" to support desired outcomes (Pfeffer, 1997) that benefit the more powerful firm. If their interests are not aligned, the focal firm's operational performance will suffer when it acts in the interests of the more powerful firm, rather than its own. There is little joint action or fine-grained information exchange, as both firms strive to protect their own interests and

This article is protected by copyright. All rights reserved. 
information exchange is constrained towards the interests of the more powerful firm. Because this archetype is characterized by relatively high power type differential and low source asymmetry (Table 2), the focal firm is subject to the detrimental effects of reward and coercive power that damage relational norms, cooperation (Skinner, et al., 1992) and relationship strength (Ke, et al., 2009; Benton \& Maloni, 2005; Maloni \& Benton, 2000).

In the strong activated power IPD, the high power type differential is weighted towards activated power, which is inversely related to the focal firm's operational performance, as described above. Both the strong and medium activated power IPDs have medium dependence asymmetry, thus, the more powerful firm will attempt to activate its reward and coercive power to constrain the focal firm's operational decisions to its own benefit. For example, a customer may threaten to withdraw its business if the focal firm does not deliver in certain lot sizes, or a supplier may supply the focal firm at a better price in exchange for a longer lead time. Both undesirable lot sizes and longer lead times are detrimental to the focal firm's operational performance. However, joint dependence is higher for the moderate activated power IPD, since it has a higher stock of all types of power. By providing the focal firm with resources that help improve its processes (expert power) that the focal firm willingly accepts, due to its identification with (referent power) and/or obligation to (legitimate power) the more powerful firm, the focal firm improves its operations in ways that compensate for the detrimental effects of activated power. For example, the focal firm may develop a flexible process that can more readily accommodate customers' varying lot size requests and suppliers' varying lead times. Thus,

This article is protected by copyright. All rights reserved. 
H2a: Strong activated power IPDs are more strongly inversely related to the focal firm's operational performance than moderate or weak activated power IPDs.

In contrast, in the low activated power IPD, joint dependence is lower, so there is less counterbalancing; however, there is less need for counterbalancing because of the low dependence asymmetry. The more powerful firm has less ability to withhold resources that are important to the focal firm's operational performance. Although the power type differential is weighted towards activated power, it is only at a medium level. Thus,

H2b: Moderate activated power IPDs are more strongly inversely related to the focal firm's operational performance than weak activated power IPDs.

In contrast, passive power's impact comes from its possession, rather than intentional activation. Passive power is associated with a positive focal firm attitude towards the relationship (Frazier \& Summers, 1986), leading to identification with and internalization of the more powerful firm's norms and values, which support joint action, fine-grained information exchange and trust. As trust increases, the focal firm becomes more open to the other firm's influence, benefitting from expertise, joint action and information exchange fostered by referent and legitimate power. In the strong passive power IPD, power type differential is high and weighted towards the beneficial effect of passive power. Dependence asymmetry is at an intermediate level, but because of the high passive power types, this IPD is positively related with the focal firm's operational performance. In the moderate passive power IPD, joint dependence is higher than in the strong passive power IPD; however, the power type differential is less. The detrimental effect of the activated power types is stronger; thus, the beneficial effects of passive power are somewhat tempered by the detrimental effects of activated power, despite higher joint dependence. Although the focal firm has some operational benefit from joint action and 
information exchange, the more powerful firm will try to bias the focal firm's operational decisions to its own benefit. Thus,

H3a: Strong passive power IPDs are more strongly related to the focal firm's operational performance than moderate or weak passive power IPDs.

In the weak passive power IPD, joint dependence and dependence asymmetry are lower. We do not expect much detrimental activation of reward and coercive power because of the low level of dependence asymmetry; the more powerful firm's power is not much greater than that of the focal firm. Thus, this IPD is expected to have a low relationship to the focal firm's operational performance.

H3b: Moderate passive power IPDs are more strongly related to the focal firm's operational performance than weak passive power IPDs.

A second way of examining power type differential is through archetypes related to power valence, ignoring activation intentionality in favor of outcomes. Although reward power is characterized by intentional activation, it can be beneficial to the focal firm through the rewards it provides. Reward, expert, referent and legitimate power are all positive power types. On the other hand, coercive power can undermine the focal firm's ability to create resources (Touboulic, et al., 2014); thus it has a negative effect that can extend upstream and downstream to the entire supply chain. In this way, coercive power can block a focal firm's ability to perform critical functions that contribute to relationship stability (Gundlach \& Cadotte, 1994).

In the strong negative power IPD, power type differential is high and weighted towards negative power. Dependence asymmetry and joint dependence are low, so the detrimental effect of this weighting is expected to dominate, with little counterbalancing by positive power types. Because of the low source asymmetry, the focal firm faces negative power from both upstream and downstream. For example, the more powerful firm may threaten to reduce or withdraw 
business or spread negative word-of-mouth about the focal firm unless it complies with its requests, no matter what their impact on the focal firm's operations. Because of its desire to avoid such outcomes, the focal firm complies with the more powerful firm's requests, to the detriment of its operational performance. In the moderate negative power IPD, power type differential, dependence asymmetry and joint dependence are at a medium level. The more powerful firm will still try to capitalize on its power; however, the total amount of power that it has is less than in the strong negative power IPD. Like the other IPDs, the level of power is low in the weak negative power IPD, so there is only a weak relationship between it and the focal firm's operational performance. We posit that:

H4a: Strong negative power IPDs are more strongly inversely related to the focal firm's operational performance than moderate or weak negative power IPDs.

H4b: Moderate negative power IPDs are more strongly inversely related to the focal firm's operational performance than weak negative power IPDs.

In contrast, although power type differential is high or medium in the positive power IPDs, it is weighted towards power types that are positively related to the focal firm's operational performance. Positive power types are associated with effective coordination, efficient exchange (Hofer, 2015), increased empathy, reduced manipulation, non-adversarial engagement (Gundlach $\&$ Cadotte, 1994), and less frequent conflict (Gulati \& Sytch, 2007). They are positively related to the focal firm's operational performance through learning, information exchange and constructive problem solving. Because source asymmetry is low, the focal firm is supported by beneficial relationships with both upstream and downstream firms. In the strong positive power IPD, power type differential is high and weighted toward positive power types. Although dependence asymmetry is also high, it is beneficial, because of the weighting toward positive power types. Therefore,

This article is protected by copyright. All rights reserved. 
$\mathbf{H}_{\mathbf{5}}$ : Strong positive power IPDs are more strongly related to the focal firm's operational performance than moderate or weak positive power IPDs.

In the moderate positive power IPD, the power type differential is less, increasing the detrimental effect of coercive power; the more powerful firm will attempt to coerce the focal firm to make operational decisions that benefit it. However, the focal firm's operational performance will be relatively strong, due to the benefits of high joint dependence. In contrast, the weak positive power IPD will have lower operational performance because of its lower joint dependence. Thus,

$\mathbf{H}_{5 \mathbf{5}}$ : Moderate positive power IPDs are more strongly related to the focal firm's operational performance than weak positive power IPDs.

The final two sets of hypotheses test the effect of power source asymmetry, where the balance of power is weighted in favor of the customer or supplier. We focus on the archetypes where the asymmetry is the greatest, which are the across-the-board source asymmetric IPDs, although many others are possible. In a supplier dominant IPD, the supplier's across-the-board power is high relative to both the focal firm (high dependence asymmetry) and the customer (high power source differential). This gives the supplier isolating mechanisms (Cox, 2001) which allow it to exploit the focal firm (Maloni \& Benton, 2000) by driving operational benefits and resources to itself (Pfeffer \& Salancik, 1978; Kim, et al., 2006). The focal firm may be reluctant to collaborate, fearing that overreliance on the supplier will lead to a "treadmill to oblivion" (Touboulic, et al., 2011) that will cause it to make continuing investments with diminishing returns. In the strong supplier dominant IPD, dependence asymmetry and power source asymmetry are high, so the focal firm is dependence disadvantaged with respect to the supplier. Joint dependence is at a moderate level, since dependence is high upstream and low downstream. Because type differential is low, little counterbalancing is expected. Thus,

This article is protected by copyright. All rights reserved. 
$\mathbf{H}_{6 \mathbf{a}}$ : Strong supplier dominant IPDs are more negatively related to the focal firm's operational performance than moderate or weak supplier dominant IPDs.

On the other hand, in a moderate supplier dominant IPD, the source differential is less and joint dependence is higher; a relatively positive relationship with the customer may provide some support to the focal firm to counterbalance the detrimental supplier relationship. In the weak supplier dominant IPD, the customer has very little power with which to counterbalance the supplier's power, however, the supplier has only a moderate level of power. Thus,

$\mathbf{H}_{6 \mathbf{b}}$ : Moderate supplier dominant IPDs are more negatively related to the focal firm's operational performance than weak supplier dominant IPDs.

In contrast, in a customer dominant IPD, source asymmetry is high, but in favor of the customer. The customer may influence the focal firm's behavior and employ adversarial tactics because it has little fear of retaliation (Ireland \& Webb, 2007; Dore, 1983). Overall, however, customer dominance is well aligned with the focal firm's operational goals (Watson, 2001) related to customer satisfaction, and the focal firm may view a customer dominant IPD as a winwin (Shi, et al., 2013) because of the attractiveness of the customer's account (Cox, 2004) and the resources it can provide. Thus,

$\mathbf{H}_{7}$ : Customer dominant IPDs are positively related to the focal firm's operational performance.

In the strong customer dominant IPD, high power source asymmetry and high dependence asymmetry combine with moderate joint dependence to have a positive impact on the focal firm's operational performance. Because power type differential is low, the beneficial effects of the customer's passive power counterbalance the detrimental effects of its activated power. Thus,

$\mathbf{H}_{7 \mathbf{a}}$ : Strong customer dominant IPDs are more strongly related to the focal firm's operational performance than moderate or weak customer dominant IPDs.

This article is protected by copyright. All rights reserved. 
In the weak customer dominant IPD, power source asymmetry is lower, thus, the focal firm is somewhat subject to both upstream and downstream influence. This influence is positive because of the lower power type differential. Thus,

$\mathbf{H}_{7 \mathbf{b}}$ : Moderate customer dependence advantage IPDs are more strongly related to the focal firm's operational performance than weak customer dominant IPDs.

\section{METHOD}

A survey instrument was developed to measure the focal firm's perceptions of upstream and downstream power and operational performance. Respondents were asked to focus on their firm's major customer (buys the highest dollar value of its products) and major supplier (supplies it with the highest dollar value of supplies), based on the approach used by Fynes and Voss (2002), Fynes et al. (2005), Morgan and Hunt (1994), Zhao, et al. (2011) and Brown et al. (1995).

All measures (Appendix A) used a Likert-type response scale (1=strongly disagree to $7=$ strongly agree). The power type measures were adapted from Brown et al. (1995) and previously used by Zhao et al. (2008). The measures for operational performance were adapted from Frohlich and Westbrook (2002), Beamon (1999), and Vickery et al. (2003), and previously used by Flynn, et al. (2010). The questionnaire was developed in English, translated into Chinese by an expert, then back-translated into English by a different expert and checked against the original English version for discrepancies. The questionnaire was pilot tested with a sample of managers in 15 firms.

The key informant approach was used to identify appropriate respondents. The pilot study indicated that there were respondents who were reliable and knowledgeable about both upstream and downstream supply chain relationship management, with job titles such as a supply chain manager, CEO, president, senior executive, vice president, senior director and senior

This article is protected by copyright. All rights reserved. 
manager. It also revealed that many of the middle managers had both upstream and downstream experience and that the top managers tended to have had multiple functional experiences and a broad perspective of the firm's operations.

Data were collected in five major cities in China: Chongqing, Tianjin, Guangzhou, Shanghai, and Hong Kong. The sampling frame consisted of the China Telecom Yellow Pages in the four mainland cities and the Directory of the Chinese Manufacturers Association in Hong Kong. One or two firms were randomly selected from each page of the Yellow Pages and the Directory, using a random number table. A total of 4,569 firms were contacted by telephone to identify potential key informants, who were sent the questionnaire, along with a cover letter highlighting the objectives of the research. Follow-up telephone calls were made to improve the response rate. One thousand three hundred fifty-six questionnaires were distributed and there were 617 usable responses, for a response rate of $45.5 \%$. Most of the respondents had been in their position for more than three years (Table 3) and should thus be knowledgeable. Early and late responses were compared on physical assets, annual sales and number of employees (Armstrong \& Overton, 1977), with t-tests revealing no significant differences.

\section{Insert Table 3 About Here}

Three approaches were used to ensure that the key informants were able to provide valid data. First, in the cover letter, we stated:

The respondent to this questionnaire should have an overall understanding of supply chain management. The best persons to answer these questions are the President, General Manager and Supply Chain Manager. If you feel that you are not the best person to answer certain questions, please ask the person who is the most knowledgeable to answer them.

Second, we compared the responses from the top managers with those from the middle managers, in order to assess whether the top managers had the same knowledge about supply chain power as the middle managers. Analysis of variance was used to compare their responses on the five

This article is protected by copyright. All rights reserved. 
types of upstream power, five types of downstream power and operational performance. Of the 11 tests, the only statistically significant difference was for customer reward power, which the top managers perceived as greater than the middle managers. The remaining ten tests were not statistically significant. Third, we divided the respondents into those with broad responsibilities (supply chain manager, general manager, president, etc.), those with upstream responsibilities (purchasing manager, materials manager, etc.) and those with downstream responsibilities (sales manager, customer relations manager, etc.). Analysis of variance was employed to test for the same differences as the test of upper versus middle managers described above. There were no significant differences between the responses of the three groups. Table 4 provides a summary of this analysis. Based on these results, we conclude that the respondents were equally capable of answering the questions in the survey.

\section{Insert Table 4 Approximately Here}

The items comprising the power and operational performance measures were not highly similar in content, and the respondents were familiar with the constructs. Harman's one-factor test (Podsakoff \& Organ, 1986; Podsakoff et al., 2003 Hochwarter et al., 2004;) indicated that there were several distinct factors among the power and performance variables. Confirmatory factor analysis (CFA) applied to Harman's single-factor model (Sanchez \& Brock, 1996) determined that common method bias was not a problem. To check for normality, P-P plots of each variable's cumulative proportion were checked against the cumulative proportion of several test distributions, and they were found to be normal. Table 5 indicates that all measures were reliable. Exploratory factor analysis (EFA) (varimax rotation) assessed unidimensionality. Three items, indicated with asterisks in Appendix A, were dropped because their factor loadings were relatively low and they loaded on two factors. The final EFA (Appendix B) indicated that all

This article is protected by copyright. All rights reserved. 
items had strong loadings on the construct they were intended to measure and lower loadings on the constructs they were not intended to measure, demonstrating unidimensionality.

\section{Insert Table 5 Approximately Here}

Discriminant and convergent validity were assessed using CFA, where each measurement item was linked to its corresponding construct and the covariance among the constructs was freely estimated. The model fit indices were Chi-square $=4,930.32$ with d.f. $=1517, \mathrm{NNFI}=$ 0.95, CFI $=0.96$, RMSEA $=0.064$ and SRMR $=0.049$. The model was acceptable $(\mathrm{Hu} \&$ Bentler, 1999), demonstrating convergent validity (Fornell \& Larcker, 1981). A constrained CFA model was built for every possible pair of latent constructs, with correlations between the pairs fixed at 1.0. It was compared with the original unconstrained model, with freely estimated correlations among constructs. Among the 78 Chi-square tests, only three were non-significant, demonstrating discriminant validity (Bagozzi, et al., 1991; Chen \& Paulraj, 2004; Fornell \& Larcker, 1981).

\section{ANALYSIS}

Cluster analysis was used to classify the respondents, allowing IPDs to emerge. Hierarchical clustering procedures determined the best number of clusters, then non-hierarchical clustering was applied to produce the final clusters (Hair, et al., 1998). The percentage of change in the agglomeration coefficient was the highest and the second highest when the number of clusters changed from two to one and from eight to seven, respectively, indicating that two or eight clusters would be appropriate. Based on Lehmann's (1979) guidelines, we used eight, rather than two, clusters, and a random sampling of dendrograms confirmed that this represented a good solution. Canonical discriminant analysis identified the underlying dimensions that defined the

This article is protected by copyright. All rights reserved. 
clusters. ANOVA tested the relationship between the IPDs and operational performance. When F was significant, Tukey's b was used to identify specific differences between the IPDs.

\section{RESULTS}

The cluster analysis results are shown in Tables 6-8 and Figure 2. None of the eight emergent IPDs resembled activated power, passive power, negative power or supplier dominant theoretical IPDs, thus we tested only $\mathrm{H}_{1}, \mathrm{H}_{5}$ and $\mathrm{H}_{6}$ and their sub-hypotheses. Table 7 indicates that the first two functions had eigenvalues larger than 1, explaining $87.0 \%$ of the variance. Between $90.3 \%$ and $98.1 \%$ of the respondents were correctly classified by the discriminant analysis, indicating high predictive ability.

Insert Table 6-8 and Figure 2 Approximately Here

Table 9 reveals statistically significant differences between operational performWilance for the IPDs. All were positively associated with operational performance overall, thus, $\mathrm{H}_{1}, \mathrm{H}_{5}$ and $\mathrm{H}_{6}$ were supported. The strong across-the-board IPD had operational performance that was significantly higher than it was for the moderate or weak across-the-board IPD, supporting $\mathrm{H}_{1 \mathrm{a}}$. Operational performance for the moderate across-the-board IPD was significantly greater than for the weak across-the-board IPD, supporting $\mathrm{H}_{1 \mathrm{~b}}$. There was not a significant difference between operational performance of the strong positive power IPD and the moderate or low positive power IPD, thus, $\mathrm{H}_{5 a}$ was not supported. The moderate customer dominant and the moderate positive power IPDs were almost identical in operational performance, and they were both significantly higher than the weak customer dominant and weak non-coercive IPDs, respectively, supporting $\mathrm{H}_{5 \mathrm{~b}}$ and $\mathrm{H}_{6 \mathrm{~b}}$. Thus, all tested hypotheses and sub-hypotheses were supported, with the exception of $\mathrm{H}_{6 \mathrm{a}}$.

Insert Table 9 Approximately Here

This article is protected by copyright. All rights reserved. 


\section{DISCUSSION}

This research examined the relationship between upstream and downstream supply chain power configurations and the operational performance of the focal firm at their intersection. It contributed to the literature on supply chain power by using interlocking power dyads as the unit of analysis. A total of 21 theoretical IPDs was developed, based on dependence asymmetry, joint dependence, power type differential and power source asymmetry. Cluster analysis yielded eight clusters of upstream and downstream power, corresponding to eight of the theoretical IPDs, providing preliminary support for our taxonomy.

We found that the overall level of power (joint dependence) in an IPD was associated with the focal firm's operational performance, consistent with predictions based on the embeddedness perspective. The IPDs with strong levels of power were related to the best levels of operational performance, followed by those with moderate levels of power. The IPDs with the weakest joint dependence were associated with the lowest levels of the focal firm's operational performance. Thus, joint dependence is positively related to performance.

The hypotheses allowed testing dependence asymmetry, in addition to joint dependence, since the focal firm was dependent on the customer and/or supplier in each of them. Thus, we could examine the effect of joint dependence and dependence asymmetry, when considered together. This research proposed power type differential as an additional factor in operational performance. We found that the across-the-board IPDs had the lowest power type differential, since the power types were at equivalent levels, within the configurations. These IPDs were associated with the best operational performance, indicating that there is a counterbalancing effect between the power types. Although coercive power was at the same level as the other power types in these IPDs, the beneficial effects of the other power types led to the best

This article is protected by copyright. All rights reserved. 
operational performance. Thus, some types of supply chain power have a beneficial effect on the focal firm's performance, compensating for the detrimental effect of other types of power. This provides support for the embeddedness perspective and expands the more limited perspective of RDT.

The positive power IPDs had high levels of reward, expert, referent and legitimate power, relative to coercive power. There was no difference between the strong positive power IPD's relationship to operational performance and the moderate or weak positive power IPDs' relationship. However, there was a significant difference between the moderate and weak positive power IPDs' relationship to the focal firm's operational performance. Although reward, expert, referent and legitimate power were related to the focal firm's operational performance, they were related at a level that was lower than the across-the-board power IPDs, since the level of joint dependence was lower in the positive power IPDs. This provides further support that joint dependence is positively related to performance.

Our findings suggest that there may be a joint dependence threshold, beyond which supply chain power becomes important. At lower joint dependence, none of the firms has enough power to have much of an impact. At high joint dependence, however, supply chain power is positively associated with operational performance. Although the strong across-the-board IPD was associated with the best operational performance, it was not significantly different from the operational performance for the strong positive power or moderate customer dominant IPDs. Thus, dependence asymmetry, power type differential and power source asymmetry are also important.

The customer dominant IPDs were high in power source asymmetry, with strong across-theboard power downstream and low across-the-board power upstream. This dependence 
asymmetry was at a somewhat lower level, since only the customer had significant power, relative to the focal firm. The moderate customer dominant IPDs were associated with better operational performance than the weak customer dominant IPDs. Furthermore, the moderate customer dominant and positive power IPDs were related to almost identical operational performance. Thus, customer power is more important in the operational performance of the focal firm, unlike supplier power. We attribute this to the importance of the customer to many aspects of operational performance, including on-time delivery, short lead times, customer service, responsiveness to market demand changes and the capability to modify products to meet customer needs. Thus, when the customer is powerful, relative to the focal firm, and the supplier is not, the focal firm's attention is directed toward creating resources through its understanding of the customer's needs. This helps improve the focal firm's operational performance, while simultaneously satisfying the customer. In other words, an IPD that contains a relatively weak supplier can be just as successful as one with a strong supplier, since a more powerful supplier doesn't help the focal firm create resources; its motives are more likely based on its own needs.

Combined, the analysis supported all of the hypotheses, except for $\mathrm{H}_{5 \mathrm{a}}$, which tested the relationship between the strong positive IPD and operational performance. They provide support for the importance of dependence asymmetry, which was illustrated in all of the strong and moderate IPDs; when the focal firm perceives strong or moderate power, the implication is that it is more dependent in these relationships. The simultaneous effect of joint dependence is supported, since the strong IPDs, which were higher in total power, were related to better operational performance than the moderate IPDs, followed by the weak IPDs. Comparison of the across-the-board IPDs with the other IPDs supports the importance of power type differential, revealing that low power type differential is related to the best performance. Finally, comparing

This article is protected by copyright. All rights reserved. 
the customer dominant and other IPDs reveals that power source differential is important; supplier power is less important to focal firm operational performance than is customer power. Thus, the results supported the importance of dependence asymmetry, joint dependence, power type differential and power source asymmetry in supply chain power.

Dependence asymmetry, joint dependence, power type differential and power source asymmetry are relatively easy to understand conceptually, providing a framework for understanding power within a segment of a supply chain. This understanding can be expanded by applying these constructs in other IPDs, building on Watson's (2001) notion of power subregimes within a supply chain. Specific power subregimes will be different within different parts of a supply chain. Understanding IPDs and their relationship with performance is a first step towards developing strategies for both dealing with the influence of power and capitalizing on it.

The cluster analysis did not yield an IPD that corresponded to activated vs. passive power. Thus, the intentionality of power did not differentiate between operational performance, counter to the expectations of the literature. Further, there were no supplier-dominant IPDs that emerged from the cluster analysis. There are several possible explanations for this. First, it may be that supplier dominance is more unusual than customer dominance. Although there may be powerful suppliers of a unique material, for example, this situation is relatively unusual. This finding may also be unique to China. Since many large Chinese manufacturers serve as suppliers to large multinational firms, they may be particularly sensitive about customer power. Finally, there were no negative power IPDs that emerged from the cluster analysis. This supports the importance of considering a configuration of power types and not focusing only on coercive power.

This article is protected by copyright. All rights reserved. 
There are several limitations of this research that lead to opportunities for future research. First, although we measured the focal firm's perceptions of supplier and customer power, we did not measure the power or dependence of the focal firm, itself. However, we could infer these based on the focal firm's perceptions of upstream and downstream power; if it perceives a high level of power, the focal firm is more dependent by definition. It is certainly conceivable that a firm could be weak relative to its customers, but strong relative to its customers, or vice versa. Thus, the IPDs that are proposed in this study are only a sampling of the population of IPDs that are possible, providing a rich opportunity for future research. Developing a better understanding of reciprocal dependence will allow future research to develop a more thorough examination of the way power relationships function in the development of resources. Although our measures of customer and supplier power were based on the focal firm's perceptions, we argue that this is the best way to measure these constructs, since power is ultimately a perceptual construct that exists in the eyes of the influenced firm.

Second, we used key informants to provide information about both customer and supplier power. Although our pilot study indicated that the respondents were well versed about both customers and suppliers, and we did not find significant differences between their responses, this approach was used, in part, because of anticipated difficulty in obtaining two reliable respondents from each firm. Issues associated with the use of a single respondent relate to the inability to determine the extent to which variation in a measurement is due to the concept of interest, systematic sources of error due to methods factors or random error (Phillips, 1981). There is also the potential for informant bias (Kumar, et al., 1993), related to the respondents' positions. To the extent possible, future research should strive to use different informants to obtain perceptions of upstream versus downstream relationships. Similarly, although we used

This article is protected by copyright. All rights reserved. 
RDT to make inferences about resource development, we did not directly measure resources or their impact. Future research should build on measurement of resource development and possession in complex supply networks.

Finally, because this research was set in China it may not be generalizable to other national cultures. Chinese national culture is particularly strong in power distance (Hofstede, 1983, 1984), which is reflected in a strong belief in knowledge and authority. These could impact perceptions of expert and legitimate power. Guanxi, which is based on the expectation of mutual favors (Zhao, et al., 2008), is an important part of Chinese national culture. This means that there could be a greater acceptance of reward power than there would be in other national cultures. Thus, replication of this research in other national cultures is important.

There are numerous opportunities for future research that builds on this study. We applied French and Raven's (1959) theoretical lens to differentiate power types, in conjunction with dependence asymmetry, joint dependence and source asymmetry. The resulting IPDs raise a number of interesting and important research questions. Because power can be developed by doing favors for others (Pfeffer, 1997), the norm of reciprocity may play a role in supply chain power (Ireland \& Webb, 2007). This suggests extending the unit of analysis from dyads to triads of firms and measuring power and dependence of the key supplier, focal firm and key customer. At a higher level, the relationship within and between power triads of different types should be examined, as a basis for preliminary analysis of power regimes within complex supply networks.

Although RDT and French and Raven's (1959) conceptualization of power types provided a solid theoretical foundation for this research, there are other theoretical foundations that may also be relevant to future research on supply chain power. Information processing theory (Galbraith, 1973, 1978), which focuses on the uncertainty created by power and mechanisms for uncertainty

This article is protected by copyright. All rights reserved. 
accommodation and reduction, may be useful in developing strategies for dealing with the uncertainties created by power in supply chain relationships. Transaction cost economics theory (Williamson, 1975, 1985; Heide \& Miner, 1992) may provide deeper insight into the opportunistic behavior that can result from dependence asymmetry, particularly in the case of investments in transaction-specific assets mandated by a more powerful firm. Institutional theory (DiMaggio \& Powell, 1983) may contribute to better articulating the pressures that emanate from institutional environments to induce a firm to adopt different practices and shared norms. For example, violating unwritten rules or norms may bring a firm's legitimacy into question, jeopardizing its access to scarce resources (Ke, et al., 2009; Czinkota, et al., 2014). Drawing upon these and other theoretical foundations will help develop a rich theoretical foundation for the study of power in complex supply networks.

This research provides a foundation for understanding the types of power that influence a firm in a supply chain. Understanding its current power position is the first step for a firm in achieving a competitive advantage within a supply chain (Cox, 2001). The next step is development of strategies for moving from its current power position to one that is more advantageous. This is complicated by the partial inclusion of a firm in many IPDs and the dynamic nature of relationships between supply chain firms (Allport, 1962). Although this research contributes to the ability of a supply chain firm to understand its power profile and its implications, there are many opportunities for future research to investigate ways in which supply chain firms can improve their power position.

This article is protected by copyright. All rights reserved. 


\section{REFERENCES}

Allport, F.H. (1962). A structuronomic conception of behavior: Individual and collective. Journal of Abnormal and Social Pschology, 64, 3-30.

Armstrong, J. S., \& Overton, T.S. (1977). Estimating nonresponse bias in mail surveys. Journal of Marketing Research, 14(3), 396-402.

Bagozzi, R.P., Yi, Y., \& Phillips, L.W. (1991). Assessing construct validity in organizational research. Administrative Science Quarterly, 36(3), 421-458.

Bastl, M., Johnson, M., \& Choi, T.Y. (2013). Who's seeking whom? Coalition behavior of a weaker player in buyer-supplier relationships. Journal of Supply Chain Management, 49(1), 8-28.

Beamon, B.M. (1999). Measuring supply chain performance. International Journal of Operations and Production Management, 19(3), 275-292.

Benton, W.C., \& Maloni, M. (2005). The influence of power driven buyer/seller relationships on supply chain satisfaction. Journal of Operations Management, 23(1), 1-22.

Bode, C. Wagner, S.M., Peterson, K.J., \& Ellram, L. (2011). Understanding responses to supply chain disruptions: Insights from information processing and resource dependence perspectives. Academy of Management Journal, 54(4), 833-856.

Brányi, T., Józsa, L. (2015). Power of companies in supply chains and their effect on network development. Journal of Economics and Management, 19(1), 221-239.

Brown, J.R., Lusch, R.F., \& Nicholson, C.Y. (1995). Power and relationship commitment: their impact on marketing channel firm performance. Journal of Retailing, 71(4), 363-392.

Cai, S. \& Yang, Z. (2008). Development of cooperative norms in the buyer-supplier relationship: the Chinese perspective. Journal of Supply Chain Management, 44(1), 55-70.

Casciaro, T. \& Piskorski, M.J.(2005). Power imbalance, mutual dependence and constraint absorption: a closer look at resource dependence theory. Administrative Science Quarterly, 50(2), 167-199.

Chen, I.J. \& Paulraj, A. (2004). Understanding supply chain management: critical research and a theoretical framework. International Journal of Production Research, 42(1), 131-163.

Choi, T.Y., \& Wu, Z. (2009). Triads in supply networks: Theorizing buyer-supplier relationships. Journal of Supply Chain Management, 45(1), 8-25.

Cox, A. (2001). Understanding buyer and supplier power: a framework for procurement and supply competence. Journal of Supply Chain Management, 37(2): 8-15.

Cox, A. (2004). The art of the possible: relationship management in power regimes and supply chains. Supply Chain Management, 9, 346-356.

Crook, T.R., \& Combs, J.G. (2007). Sources and consequences of bargaining power in supply chains. Journal of Operations Management, 25, 546-555.

Czinkota, M., Kaufmann, H.R. \& Basile, G. (2014). The relationship between legitimacy, reputation, sustainability and branding for companies and their supply chains. Industrial Marketing Management, 43(1), 91-101.

Dipiran, G.P. \& Hogarth-Scott, S. (2003). Are cooperation and trust being confused with power? An analysis of food retailing in Australia and the UK. International Journal of Retailing and Distribution Management, 31(4/5), 256-267.

DiMaggio, P.J. \& Powell, W.W. (1983). The iron cage revisited: institutional isomorphism and collective rationality in organizational fields. American Sociological Review, 48, 147-160.

Dore, R. (1983). Goodwill and the spirit of market capitalism. British Journal of Sociology, 34(4),

This article is protected by copyright. All rights reserved. 
459-482.

Drea, J.T., Bruner, G.C., \& Hinsch, P.J. (1993). Comparing alternative measures of the French and Raven power types. Journal of Personal Selling and Sales Management, 8(4), 73-80.

Dyer, J.H. (2000). Collaborative Advantage: Winning through Extended Enterprise Supplier Networks. Oxford: Oxford University Press.

Emerson, R.E. (1962). Power-dependence relations. American Sociological Review, 27, 31-41.

Fiol, M., O'Connor, E.J., Aguinis, H. (2001). All for one and one for all? The development and transfer of power across organizational levels. Academy of Management Journal, 26(2), 224-242.

Flynn, B.B., Huo, B. \& Zhao, X. (2010). The impact of supply chain integration on performance: a contingency and configuration approach. Journal of Operations Management, 28(1), 58.

Fornell, C., \& Larcker, D.F. (1981). Evaluating structural equation models with unobservable variables and measurement error. Journal of Marketing Research, 18(1), 9-50.

Frazier, G.L., \& Summers, J.O. (1986). Perceptions of interfirm power and its use within a franchise channel of distribution. Journal of Marketing Research, 23, 169-176.

French, R.P., \& Raven, B.H. (1959). The types of social power, in Dorwin Cartwright (Ed.): Studies in social power. University of Michigan Press, Ann Arbor, MI, 155-164.

Frohlich, M.T. \& Westbrook, R. (2002). Arcs of integration: an international study of supply chain strategies. Journal of Operations Management, 19(2), 185-200.

Frost, D.E., \& Stahelski, A.J. (1988). The systematic measurement of French and Raven's bases of social power in workgroups. Journal of Applied Social Psychology, 18(5): 375-389.

Fynes, B. \& Voss, C. (2002). The moderating effect of buyer-supplier relationships on quality practices and performance. International Journal of Operations and Production Management, 22(5/6), 589.

Fynes, B., Voss, C. \& deBurca, S. (2005). The impact of supply chain relationship dynamics on manufacturinig performance. International Journal of Operations and Production Management, 5(1), 6-19.

Galbraith, J. (1973). Designing Complex Organizations. Reading, MA: Addison-Wesley.

Galbraith, J. (1978). Organizational design: an information processing view. Interfaces, 4(3), 2836.

Gassenheimer, J.B. \& Ramsey, R. (1994). The impact of dependence on dealer satisfaction: a comparison of reseller-supplier relationships. Journal of Retailing, 70(3), 253.

Granovetter, M. (1985). Economic action and social structure: the problem of embeddedness. American Journal of Sociology, 91, 481-510.

Gulati, R. \& Sytch, M. (2007). Dependence asymmetry and joint dependence in interorganizational relationships: effects of embeddedness on a manufacturer's performance in procurement relationships. Administrative Science Quarterly, 52, 32-69.

Gundlach, G.T., \& Cadotte, E.R. (1994). Exchange interdependence and interfirm interaction: Research in a simulated channel setting. Journal of Marketing Research, 31(4), 516-532.

Hair, J.F., Anderson, R.E., Tatham, R.I., \& Black, W.C. (1998). Multivariate data analysis. Prentice Hall, Englewood Cliffs, New Jersey.

He, Q., Ghobadian, A., \& Gallear, D. (2013). Knowledge acquisition in supply chain partnerships: The role of power. International Journal of Production Economics, 141, 605-618.

Heide, J.B. \& Miner, A.S. (1992). The shadow of the future: effects of anticipated interaction and frequency of contact on buyer-supplier cooperation. Academy of Management Journal,

This article is protected by copyright. All rights reserved. 
35(1), 265.

Hochwarter, W.A., James, M., Johnson, D., \& Ferris, F.R. (2004). The interactive effects of politics perceptions and trait cynicism on work outcomes. Journal of Leadership and Organizational Studies, 10(4),44-57.

Hofer, A.R. (2015). Are we in this together? The dynamics and performance implications of dependence asymmetry and joint dependence in logistics outsourcing relationships. Transportation Journal, 54(4), 438.

Hofstede, G. (1983). The cultural relativity of organizational practices and theories. Journal of International Business Studies, 14(6), 75-89.

Hofstede, G. (1984). Culture's consquences. Thousand Oaks, CA: Sage.

Hu, L., \& Bentler, P.M. (1999). Cutoff criteria for fit indices in covariance structure analysis: conventional criteria versus new alternatives. Structural Equation Modeling, 6(1), 1.

Huber, G.P. (2001). Transfer of knowledge in knowledge management systems: unexplored issues and suggested studies. European Journal of Information Systems, 10(2), 72-79.

Hult, G.T.M., Ketchen, D.J. Jr. \& Slater, S.F. (2004). Information processing, knowledge development and strategic supply chain performance. Academy of Management Journal, 47(2), 241-253.

Ireland, D., \& Webb, J.W. (2007). A multi-theoretic perspective on trust and power in strategic supply chains. Journal of Operations Management, 25(2), 482-97.

Jap, S.D. \& Ganeson, S. (2000). Control mechanisms and the relationship life cycle: implications for safeguarding specific investments and developing commitment. Journal of Marketing Research, 37, 227-245.

Joshi, A.W. \& Campbell, A.J. (2003). Effects of environmental dynamism on relational governance in manufacturer-supplier relaitonsips: a contingency framework and an empirical test. Academy of Marketing Science, 31(2), 176.

Ke, W., Liu, H., Wei, K.K., Gu, J., \& chen, H. (2009). How do mediated and non-mediated power affect electronic supply chain management system adoption? The mediating effects of trust and institutional pressures. Decision Support Systems, 46, 839-851.

Kim, D., Cavusgil, S.T. \& Calantone, R.J. (2006). Information system innovations and supply chain channel relationships and firm performance. Journal of the Academy of Marketing Science, 34(1), 40-54.

Kumar, N., Stern, L.W., \& Anderson, J.C. (1993). Conducting interorganizational research using key informants. Academy of Management Journal, 36(6), 1633-1651.

Kumar, , N., Scheer, L.K. \& Steenkamp, J.E.M. (1995). The effects of perceived independence on dealer attitudes. Journal of Marketing Research, 32(August), 348-356.

Lawler, , E.J., Thyl, S.R., Yoon, J. (2000). Emotion and group cohesion in productive exchange. American Journal of Sociology, 106(3), 616-657.

Lehmann, D.R. (1979). Market Research and Analysis. Homewood, IL: Irwin.

Lusch, R.F., \& Brown, J.R. (1982). A modified model of power in the marketing channel. Journal of Marketing Research, 19, 312-323.

Maloni, M., \& Benton, W.C. (2000). Power influences in the supply chain. Journal of Business Logistics, 21(1), 49-73.

March, J.G. (1966). The power of power. In Easton, D., ed., Varieties of Political Theory. Englewood Cliffs, NJ: Prentice-Hall, 39-70.

Miszruchi, M.S. (1989). Similarity of political behavior among large American corporations. American Journal of Sociology, 95, 401-424.

This article is protected by copyright. All rights reserved. 
Morgan, R.M. \& Hunt, S.D. (1994). The commitment-trust theory of relationship marketing. Journal of Marketing, 58, 20-38.

Nielson, C.C. (1996). An empirical examination of switching cost investments in business-tobusiness marketing relationships. Journal of Business and Industrial Marketing, 11(6), 38-60.

Pfeffer, J. (1997). New Directioins for Organization Theory. New York: Oxford University Press.

Pfeffer, J., \& Salancik, G.R. (1978). The External Control of Organizations: A Resource Dependence Perspective. Stanford University Press: Stanford, California.

Phillips, L.W. (1981). Assessing measurement error in key informant reports: A methodological note on organizational analysis in marketing. Journal of Marketing Research, 18, 395-415.

Podsakoff, P.M., MacKenzie, S.B., Lee, J.Y. \& Podsakoff, N.P. (2003). Common method bias in behavioral research: A critical review of the literature and recommended remedies. Journal of Applied Psychology, 88(5), 879-903.

Podsakoff, P.M. \& Organ, D.W. (1986). Self-reports of organizational research: Problems and prospects. Journal of Management, 12(4), 531-544.

Provan, K. (1993). Embeddedness, interdependence and opportunism in supplier-buyer networks. Journal of Management, 19(4), 841-856.

Raven, B.H., Schwarzwald, J., \& Koslowsky, M. (1998). Conceptualizing and measuring a power/interaction model of interpersonal influence. Journal of Applied Social Psychology, 28(1): 307-322.

Sanchez, J.I., \& Brock, P. (1996). Outcomes of perceived discrimination among Hispanic employees: Is diversity management a luxury or a necessity? Academy of Management Journal, 39(3): 704-719.

Shi, R., Zhang, J., \& Ru, J. (2013). Impacts of power structure on supply chains with uncertain demand. Production and operations Management, 22(5), 1232-1249.

Skinner, S.J., Gassenheimer J.B., \& Kelley, S.W. (1992). Cooperation in supplier-dealer relations. Journal of Retailing, 68, 174-193.

Sullivan, G.L., \& O’Connor, P.J. (1985). Social power-based print advertising: Theoretical and practical considerations. Psychology and Marketing, 2(3), 217-

Tedeschi, J.T., Schlenker, B.R., \& Lindskold, S. (1972). The exercise of power and influence: The source of influence. The Social Influence Process, Aldine-Atherton, Chicago, 287375.

Touboulic, A., Chicksand, C., \& Walker, H. (2014). Managing imbalanced supply chain relationships for sustainability: A power perspective. Decision Sciences, 45(4), 577-619.

Vickery, S.K., Droge, C. Markland, R.E. (1997). Dimensions of competitive strength in manufacturing: an analysis of competitive priorities in the furniture industry. Journal of Operations Management, 15, 317-330.

Watson, G. (2001). Subregimes of power and integrated supply chain management. Journal of Supply Chain Management, Spring, 36-41.

Wetzels, M., de Ruyter, K., \& van Beigelen, M. (1998).Marketing service relationships: the role of commitment. Journal of Business and Industrial Marketing, 13(4/5), 406-423.

Williamson, O.E. (1975). Markets and Hierarchies: Analysis and Anti-Trust Implications. New York: Free Press.

Williamson, O.E. (1985). The Economic Institutions of Capitalism. New York: Free Press.

Yan, T. \& Nair, A. (2016). Structuring supplier involvement in new product development: a China-U.S. study. Decision Sciences, 47(4), 589.

This article is protected by copyright. All rights reserved. 
Yu, C.M.J. \& Liao, T.J. (2008). The impact of governance mechanisms on transaction-specific investments in supplier manufacturer relationships: a comparison of local and foreign manufacturers. Management International Review, 48(1), 95-114.

Zaheer, A. \& Venkatramann, N. (1995). Relational governance as an interorganizational strategy: an empirical test of the role of trust in economic exchange. Strategic Management Journal, $16(5), 373$.

Zhao, X., Huo, B., Selen, W. \& Yeung, J. (2011). The impact of internal integration and relationship commitment on external integration. Journal of Operations Mangement, 29(1/2), 17.

Zhao, X., Flynn, B.B. \& Roth, A.V. (2006). Decision sciences research in China: a critical review and research agenda - foundations and overview. Decision Sciences, 37(4), 451-496.

Zhao, X., Huo, B., Flynn, B.B. \& Yeung, J. (2008). The impact of power and relationship commitment on the integration between manufacturers and customers in a supply chain. Journal of Operations Management, 26(3), 368-388.

This article is protected by copyright. All rights reserved. 
This article has been accepted for publication and undergone full peer review but has not been through the copyediting, typesetting, pagination and proofreading process, which may lead to differences between this version and the Version of Record. Please cite this article as doi: $10.1111 / \mathrm{jscm} .12139$

This article is protected by copyright. All rights reserved. 
APPENDIX A

\section{Construct Measurement}

\section{Power Types (Adapted from Brown, et al., 1995)}

\begin{tabular}{|l|}
\hline \multicolumn{1}{|c|}{ Supplier Power } \\
\hline \hline EXPERT POWER
\end{tabular}

The people in our major supplier's organization know what they are doing.

We usually get good advice from our major supplier.

Our major supplier has specially trained people who really know what has to be done.

Our major supplier's business expertise makes it likely to suggest the proper thing to do.

\section{REFERENT POWER}

We really admire the way our major supplier runs its business, so we try to follow its lead.

We generally want to operate our company very similar to the way we think our major supplier would.

Our company does what our major supplier wants because we have very similar feelings about the way a business should be run.

*Because our company is proud to be affiliated with its major supplier, we often do what it asks.

\section{LEGITIMATE POWER}

It is our duty to do as our major supplier requests.

We have an obligation to do what our major supplier wants, even though it isn't a part of the contract.

Since it is our major supplier, we accept its recommendations.

Our major supplier has the right to expect us to go along with its requests.

The people in our major customer's organization know what they are doing.

We usually get good advice from our major customer.

Our major customer has specially trained people who really know what has to be done.

Our major customer's business expertise made it likely to suggest the proper thing to do.

\section{REWARD POWER}

If we do not do what as our major supplier asks, we would not have received very good treatment from it.

We really admire the way our major customer runs its business, so we try to follow its lead.

We generally want to operate our company very similar to the way we think our major customer would.

Our company does what our major customer wants because we have very similar feelings about the way a business should be run.

*Because our company is proud to be affiliated with its major customer, we often do what it asks.

It is our duty to do as our major customer requests.

We have an obligation to do what the major customer wants, even though it isn't a part of the contract.

Since it is our major customer, we accept its recommendations.

Our major customer has the right to expect us to go along with its requests.

This article is protected by copyright. All rights reserved. 


\begin{tabular}{|c|c|}
\hline $\begin{array}{l}\text { We feel that, by going along with o } \\
\text { favored on some occasions. } \\
\text { By going along with our major supp } \\
\text { some of the problems other customer } \\
\text { Our major supplier often rewards us } \\
\text { with its wishes. }\end{array}$ & $\begin{array}{l}\text { By going along with our major customer's requests, we have avoided } \\
\text { some of the problems other suppliers face. } \\
\text { Our major customer often rewards us to get our company to go along } \\
\text { with its wishes. }\end{array}$ \\
\hline \multicolumn{2}{|l|}{ COERCIVE POWER } \\
\hline $\begin{array}{l}\text { Our major supplier's personnel will so } \\
\text { do as they ask and they find out. } \\
\text { Our major supplier often hints that } \\
\text { would reduce our profits if we do not } 9 \\
\text { Our major supplier might withdraw c } \\
\text { we do not go along with it. } \\
\text { If our company does not agree to it: } \\
\text { could make things more difficult for us }\end{array}$ & $\begin{array}{l}\text { would reduce our profits if we } \\
\text { Our major customer might witl } \\
\text { we do not go along with it. } \\
\text { If our company does not agre } \\
\text { can make things more difficult }\end{array}$ \\
\hline \multicolumn{2}{|c|}{ Operational Performance (Adapted from Frohlich \& Westbrook, 2002; Beamon, 1999; Vickery, et al., 2003) } \\
\hline \multicolumn{2}{|c|}{$\begin{array}{l}\text { Our company can quickly modify products to meet our major customer's requirements. } \\
\text { Our company can quickly introduce new products into the markets. } \\
\text { Our company can quickly respond to changes in market demand. } \\
\text { Our company has an outstanding on-time delivery record with our major customer. } \\
\text { Our lead time for fulfilling customers' orders (the time which elapses between the receipt of customer's order and the delivery of the goods) is } \\
\text { short. } \\
\text { Our company provides a high level of customer service to its major customer. } \\
\text { *Our company's inventory level is low. }\end{array}$} \\
\hline
\end{tabular}

This article is protected by copyright. All rights reserved. 

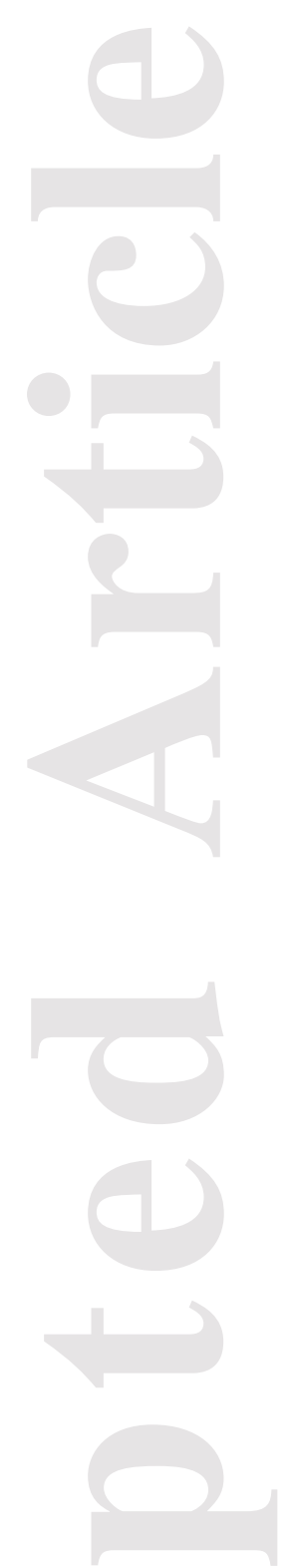

This article has been accepted for publication and undergone full peer review but has not been through the copyediting, typesetting, pagination and proofreading process, which may lead to differences between this version and the Version of Record. Please cite this article as doi:

$10.1111 /$ jscm. 12139

This article is protected by copyright. All rights reserved. 
APPENDIX B1

Factor Analysis of Power Types

\begin{tabular}{|c|c|c|c|c|c|c|c|c|c|c|c|}
\hline \multicolumn{12}{|c|}{ FACTOR LOADINGS } \\
\hline & \multicolumn{5}{|c|}{ Customer Power } & & \multicolumn{5}{|c|}{ Supplier Power } \\
\hline & Coercive & Legitimate & Expert & Referent & Reward & & Coercive & Legitimate & Expert & Referent & Reward \\
\hline Co2 & 0.901 & 0.096 & 0.012 & 0.070 & 0.125 & $\mathrm{Co} 2$ & 0.898 & 0.212 & 0.017 & 0.201 & 0.110 \\
\hline Co4 & 0.870 & 0.106 & 0.019 & 0.059 & 0.143 & $\mathrm{Co} 4$ & 0.863 & 0.226 & 0.050 & 0.221 & 0.120 \\
\hline Co3 & 0.862 & 0.142 & 0.043 & 0.024 & 0.227 & Co1 & 0.846 & 0.192 & 0.059 & 0.204 & 0.135 \\
\hline Co1 & 0.827 & 0.087 & -0.044 & 0.073 & 0.204 & $\mathrm{Co3}$ & 0.843 & 0.166 & 0.045 & 0.269 & 0.099 \\
\hline Lg1 & 0.076 & 0.777 & 0.238 & 0.136 & 0.112 & Lg2 & 0.339 & 0.807 & 0.117 & 0.173 & 0.204 \\
\hline Lg2 & 0.118 & 0.773 & 0.115 & 0.184 & 0.145 & Lg1 & 0.305 & 0.793 & 0.094 & 0.190 & 0.278 \\
\hline Lg3 & 0.107 & 0.725 & 0.215 & 0.155 & 0.158 & Lg3 & 0.161 & 0.756 & 0.211 & 0.300 & 0.134 \\
\hline $\operatorname{Lg} 4$ & 0.117 & 0.697 & 0.118 & 0.046 & 0.367 & $\operatorname{Lg} 4$ & 0.183 & 0.609 & 0.110 & 0.480 & 0.185 \\
\hline Ex2 & 0.019 & 0.099 & 0.806 & 0.196 & 0.169 & Ex3 & -0.005 & 0.085 & 0.846 & -0.011 & 0.245 \\
\hline Ex1 & -0.026 & 0.177 & 0.787 & 0.104 & 0.126 & Ex1 & 0.031 & 0.094 & 0.830 & -0.044 & 0.104 \\
\hline Ex3 & -0.102 & 0.119 & 0.777 & 0.271 & 0.102 & Ex2 & 0.022 & 0.119 & 0.761 & 0.177 & 0.225 \\
\hline Ex4 & 0.160 & 0.301 & 0.616 & 0.164 & 0.088 & Ex4 & 0.106 & 0.091 & 0.594 & 0.298 & 0.140 \\
\hline Rf2 & 0.099 & 0.162 & 0.199 & 0.858 & 0.166 & Rw2 & 0.291 & 0.252 & 0.111 & 0.792 & 0.141 \\
\hline Rf1 & 0.062 & 0.135 & 0.248 & 0.826 & 0.153 & Rw3 & 0.298 & 0.281 & 0.205 & 0.748 & 0.190 \\
\hline Rf3 & 0.067 & 0.204 & 0.241 & 0.799 & 0.159 & Rw4 & 0.461 & 0.218 & 0.019 & 0.629 & 0.258 \\
\hline Rw2 & 0.212 & 0.290 & 0.161 & 0.151 & 0.767 & Rw1 & 0.463 & 0.359 & 0.107 & 0.599 & 0.084 \\
\hline Rw3 & 0.186 & 0.261 & 0.277 & 0.158 & 0.738 & Rf2 & 0.160 & 0.197 & 0.297 & 0.208 & 0.844 \\
\hline Rw4 & 0.347 & 0.081 & 0.161 & 0.220 & 0.645 & Rf1 & 0.105 & 0.161 & 0.361 & 0.128 & 0.817 \\
\hline $\mathrm{Rw}$ & 0.308 & 0.439 & 0.018 & 0.159 & 0.589 & Rf3 & 0.205 & 0.311 & 0.224 & 0.177 & 0.749 \\
\hline Eig. & 3.389 & 2.843 & 2.675 & 2.4520 & 2.357 & Eig. & 3.936 & 2.902 & 2.758 & 2.745 & 2.437 \\
\hline
\end{tabular}

Ex $=$ expert power, $\mathrm{Rf}=$ referent power, $\mathrm{Lg}=$ legitimate power, $\mathrm{Rw}=$ reward power, $\mathrm{Co}=$ coercive power.

\section{APPENDIX B2}

Factor Analysis of Operational Performance

\begin{tabular}{lc} 
& Factor Loading \\
\hline OPF1 & .808 \\
OPF3 & .801 \\
OPF4 & .785 \\
OPF5 & .771 \\
OPF6 & .749 \\
OPF2 & .719 \\
Eigenvalue & 3.584 \\
$\quad$ Total variance explained & $59.735 \%$
\end{tabular}

This article is protected by copyright. All rights reserved. 
This article has been accepted for publication and undergone full peer review but has not been through the copyediting, typesetting, pagination and proofreading process, which may lead to differences between this version and the Version of Record. Please cite this article as doi: $10.1111 / \mathrm{jscm} .12139$

This article is protected by copyright. All rights reserved. 
TABLE 1

Types of Supply Chain Power

\begin{tabular}{|c|c|c|c|}
\hline & Definition & Assumptions & Supply Chain Examples \\
\hline Reward power & $\begin{array}{l}\text { Source promises positive outcomes } \\
\text { or removal of negative outcomes } \\
\text { for the target. }\end{array}$ & $\begin{array}{l}\text { Source has access to resources } \\
\text { that are valued by the target. }\end{array}$ & $\begin{array}{l}\text { Supplier promises to reduce prices or } \\
\text { deliver more quickly. } \\
\text { - Customer promises increase in future } \\
\text { business or to pay a higher price. }\end{array}$ \\
\hline Coercive power & $\begin{array}{l}\text { Source threatens to deliver aversive } \\
\text { outcomes or fail to deliver positive } \\
\text { outcomes to the target }\end{array}$ & $\begin{array}{l}\text { Source has access to resources } \\
\text { that increase the credibility of its } \\
\text { threats. }\end{array}$ & $\begin{array}{l}\text { Supplier threatens to slow down } \\
\text { shipments or to reduce target's priority. } \\
\text { - Customer threatens to withdraw future } \\
\text { business or exclusive territory rights. }\end{array}$ \\
\hline Expert power & $\begin{array}{l}\text { Target believes that the source } \\
\text { knows what is best to do in a } \\
\text { particular situation, compared to its } \\
\text { own knowledge or against an } \\
\text { absolute standard. }\end{array}$ & $\begin{array}{l}\text { Target believes that source has } \\
\text { knowledge or expertise that it } \\
\text { doesn't possess. }\end{array}$ & $\begin{array}{l}\text { - Focal firm values supplier's insights } \\
\text { about how to use its materials in product } \\
\text { development } \\
\text { - Focal firm values customer's guidance in } \\
\text { developing a Six Sigma initiative. }\end{array}$ \\
\hline Referent power & $\begin{array}{l}\text { Target desires to identify with and } \\
\text { be similar to an esteemed source. }\end{array}$ & $\begin{array}{l}\text { Target believes that source is } \\
\text { highly esteemed. }\end{array}$ & $\begin{array}{l}\text { Focal firm advertises that it only } \\
\text { purchases from American suppliers. } \\
\text { - Focal firm displays plaques featuring the } \\
\text { names of its well-known customers. }\end{array}$ \\
\hline Legitimate power & $\begin{array}{l}\text { Target believes that target has } \\
\text { authority over it, based on its } \\
\text { organizational role or position. }\end{array}$ & $\begin{array}{l}\text { Target's internalized values } \\
\text { dictate that the source has a } \\
\text { genuine right to influence it and } \\
\text { that it is obligated to accept that } \\
\text { influence. }\end{array}$ & $\begin{array}{l}\text { Focal firm feels obligated to purchase } \\
\text { components from another division of its } \\
\text { corporation. } \\
\text { - Focal firm believes that the customer is } \\
\text { always right. }\end{array}$ \\
\hline
\end{tabular}

This article is protected by copyright. All rights reserved. 
TABLE 2

Characteristics of Theoretical Interlocking Power Dyads

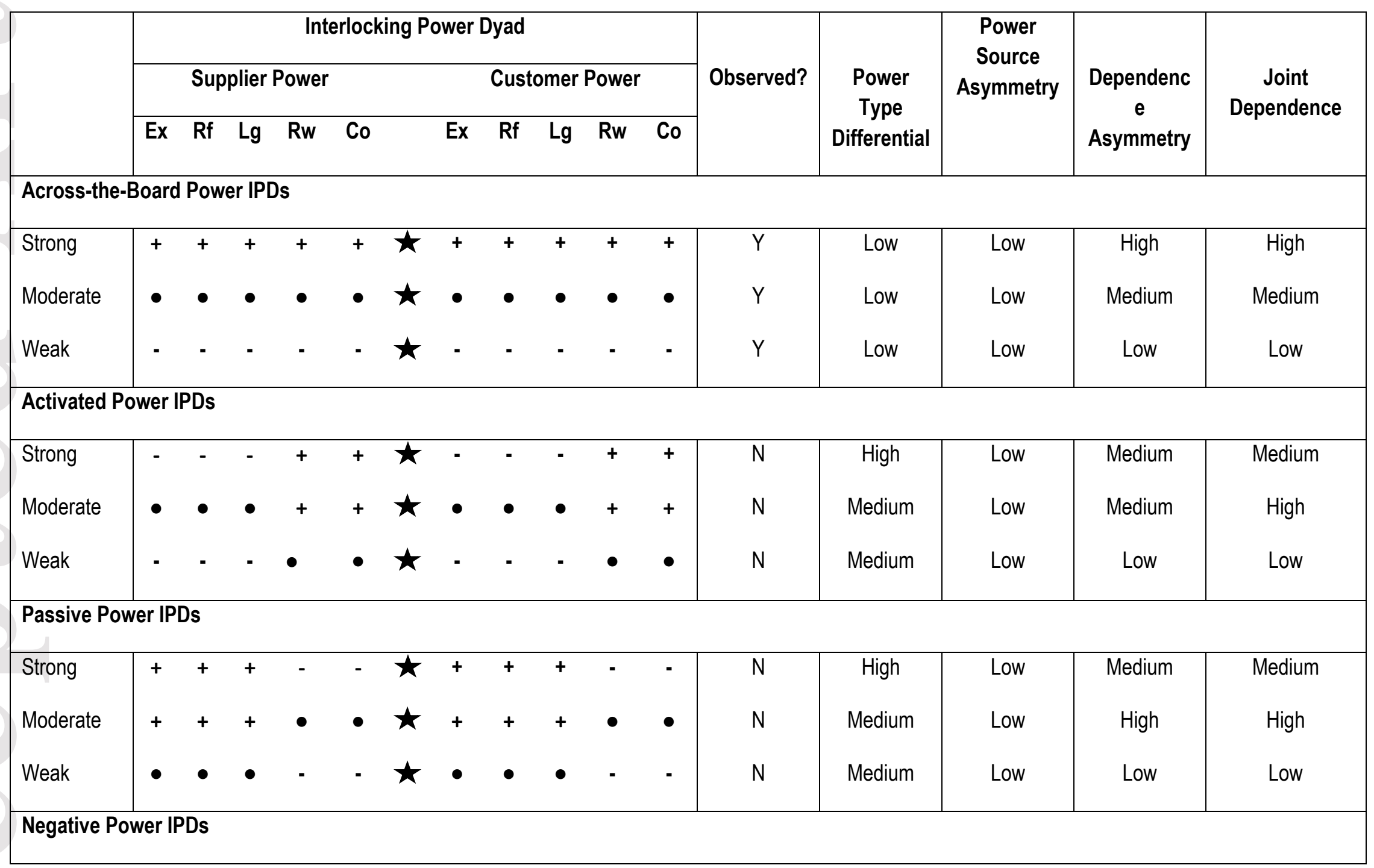

This article is protected by copyright. All rights reserved. 


\begin{tabular}{|c|c|c|c|c|c|c|c|c|c|c|c|c|c|c|c|c|}
\hline & \multicolumn{11}{|c|}{ Interlocking Power Dyad } & \multirow{3}{*}{ Observed? } & \multirow{3}{*}{$\begin{array}{c}\text { Power } \\
\text { Type } \\
\text { Differential }\end{array}$} & \multirow{3}{*}{$\begin{array}{c}\text { Power } \\
\text { Source } \\
\text { Asymmetry }\end{array}$} & \multirow{3}{*}{$\begin{array}{l}\text { Dependenc } \\
\text { e } \\
\text { Asymmetry }\end{array}$} & \multirow{3}{*}{$\begin{array}{c}\text { Joint } \\
\text { Dependence }\end{array}$} \\
\hline & \multicolumn{5}{|c|}{ Supplier Power } & & \multicolumn{5}{|c|}{ Customer Power } & & & & & \\
\hline & Ex & & Lg & Rw & Co & & Ex & $R f$ & Lg & $\mathrm{Rw}$ & Co & & & & & \\
\hline Strong & - & - & - & - & + & $\star x$ & - & - & - & - & + & $\mathrm{N}$ & High & Low & Low & Low \\
\hline Moderate & $\bullet$ & $\bullet$ & $\bullet$ & $\bullet$ & + & $\star$ & $\bullet$ & $\bullet$ & $\bullet$ & $\bullet$ & + & $\mathrm{N}$ & Medium & Low & Medium & Medium \\
\hline Weak & - & - & - & - & $\bullet$ & $\star$ & - & - & - & - & $\bullet$ & $\mathrm{N}$ & Medium & Low & Low & Low \\
\hline \multicolumn{17}{|c|}{ Positive Power IPDs } \\
\hline Strong & + & + & + & + & - & $\star$ & + & + & + & + & - & $\mathrm{Y}$ & High & Low & High & High \\
\hline Moderate & + & + & + & + & $\bullet$ & $\star$ & + & + & + & + & $\bullet$ & $Y$ & Medium & Low & High & High \\
\hline Weak & $\bullet$ & $\bullet$ & $\bullet$ & $\bullet$ & - & $\star$ & $\bullet$ & • & $\bullet$ & $\bullet$ & - & $Y$ & Medium & Low & Medium & Medium \\
\hline \multicolumn{17}{|c|}{ Supplier Dominant IPDs } \\
\hline Strong & + & + & + & + & + & $\star$ & - & - & - & - & - & $\mathrm{N}$ & Low & High & High & Medium \\
\hline Moderate & + & + & + & + & + & $\star$ & $\bullet$ & $\bullet$ & $\bullet$ & • & $\bullet$ & $\mathrm{N}$ & Low & Medium & High & High \\
\hline Weak & $\bullet$ & $\bullet$ & $\bullet$ & • & $\bullet$ & $\star$ & - & - & - & - & - & $\mathrm{N}$ & Low & Medium & Medium & Low \\
\hline \multicolumn{17}{|c|}{ Customer Dominant IPDs } \\
\hline Strong & - & - & - & - & - & $\star$ & + & + & + & + & + & $\mathrm{N}$ & Low & High & High & Medium \\
\hline Moderate & • & $\bullet$ & $\bullet$ & • & • & $\star$ & + & + & + & + & + & $Y$ & Low & Medium & High & High \\
\hline Weak & - & - & - & - & - & $\star$ & $\bullet$ & $\bullet$ & $\bullet$ & • & $\bullet$ & Y & Low & Medium & Medium & Low \\
\hline
\end{tabular}

$\star=$ focal firm, $+=$ high, $\bullet=$ medium, $-=$ low. Ex $=$ expert power, $\mathrm{Rf}=$ referent power, $\mathrm{Lg}=$ legitimate power, $\mathrm{Rw}=$ reward power, $\mathrm{Co}=$ coercive power

This article is protected by copyright. All rights reserved. 
TABLE 3

Profile of Respondents

\begin{tabular}{|c|c|c|c|}
\hline Industry & $\%$ & Sales & $\%$ \\
\hline Arts and crafts & 1.9 & $<\mathrm{HK} \$ 5 \mathrm{M}$ & 32.4 \\
\hline Building materials & 5.0 & $\mathrm{HK} \$ 5 \mathrm{M}$ to $\mathrm{HK} \$ 10 \mathrm{M}$ & 14.1 \\
\hline Chemicals and petrochemicals & 6.3 & HK\$ $10 \mathrm{M}$ to $\mathrm{HK} \$ 20 \mathrm{M}$ & 12.4 \\
\hline Electronics and electrical & 13.1 & HK\$ $20 \mathrm{M}$ to HK\$ 50M & 15.8 \\
\hline Food, beverage and alcohol & 4.9 & $\mathrm{HK} \$ 50 \mathrm{M}$ to $\mathrm{HK} \$ 100 \mathrm{M}$ & 10.2 \\
\hline Jewelry & 0.5 & HK\$ $100 \mathrm{M}$ or more & 15.0 \\
\hline Metal, mechanical and engineering & 25.4 & & \\
\hline Pharmaceutical and medical & 1.8 & & \\
\hline Printing and publishing & 4.4 & & \\
\hline Rubber and plastics & 6.6 & & \\
\hline Textiles and apparel & 17.8 & & \\
\hline Toys & 1.3 & & \\
\hline Wood and furniture & 1.9 & & \\
\hline Position & $\%$ & Years in Current Position & $\%$ \\
\hline Top management & 39.9 & $1-3$ years & 26.9 \\
\hline Middle management & 56.9 & 4-6 years & 22.9 \\
\hline \multirow[t]{2}{*}{ Other } & 3.2 & $7-12$ years & 24.6 \\
\hline & & More than 12 years & 25.6 \\
\hline
\end{tabular}

This article is protected by copyright. All rights reserved. 
TABLE 4

Assessment of Validity of Respondents

Test of Respondent Level

Mean

$\begin{array}{cccc}\text { Top Managers } & \text { Middle Managers } & \begin{array}{c}\text { Significance } \\ \text { Level }\end{array}\end{array}$

Customer power

Expert

5.14

5.00

2.63

.11

Referent

4.52

4.38

1.89

.17

Legitimate

5.14

4.96

3.66

.06

Reward

4.55

4.30

6.11

.01

Coercive

3.74

3.50

3.60

.06

Supplier Power

4.74

4.68

.44

.51

Expert

Referent

4.01

3.93

.63

.43

Legitimate

3.64

3.53

.83

.36

Reward

3.59

3.50

.62

.43

Coercive

2.93

2.86

.30

.59

$\underline{\text { Performance }}$

5.38

5.34

.27

.61

Operational

Performance

This article is protected by copyright. All rights reserved. 


$\begin{array}{ccccc} & \text { Mean } & & \\ \text { Upstream } & \text { General } & \begin{array}{c}\text { Downstream } \\ \text { Management }\end{array} & \text { F } & \begin{array}{c}\text { Significance } \\ \text { Level }\end{array} \\ \text { Management } & \text { Management } & & \end{array}$

Customer power

Expert

4.84

5.06

5.12

.81

.45

Referent

4.06

4.47

4.33

1.80

.17

Legitimate

4.71

5.03

5.09

1.34

.26

Reward

3.98

4.42

4.39

1.98

.14

Coercive

3.29

3.59

3.64

.61

.54

$\underline{\text { Supplier power }}$

4.71

4.70

4.79

.21

.81

Expert

Referent

3.75

3.98

3.94

.51

.60

Legitimate

3.31

3.56

3.74

.98

.38

Reward

3.21

3.54

3.52

.82

.44

Coercive

2.78

2.90

2.69

.64

.53

Performance

5.34

5.34

5.37

.03

.97

Operational

Performance

This article is protected by copyright. All rights reserved. 
TABLE 5

Reliability Analysis

\begin{tabular}{lcc}
\hline & \# of items & Cronbach's Alpha \\
\hline Customer power & & \\
Expert & 4 & 0.813 \\
Referent & 3 & 0.875 \\
Legitimate & 4 & 0.825 \\
Reward & 4 & 0.831 \\
Coercive & 4 & 0.915 \\
Supplier power & & \\
Expert & 4 & \\
Referent & 4 & 0.803 \\
Legitimate & 3 & 0.903 \\
Reward & 4 & 0.892 \\
Coercive & 4 & 0.894 \\
Operational performance & 4 & 0.942 \\
\hline
\end{tabular}

TABLE 6

Cluster Means

\begin{tabular}{|c|c|c|c|c|c|c|c|c|c|c|c|}
\hline \multirow[b]{2}{*}{$\begin{array}{l}\text { Cluste } \\
\mathbf{r}\end{array}$} & \multicolumn{5}{|c|}{ Customer Power $(\bar{X})$} & \multicolumn{6}{|c|}{ Supplier Power $(\bar{X})$} \\
\hline & $\begin{array}{c}\text { Expe } \\
\text { rt }\end{array}$ & $\begin{array}{c}\text { Refer } \\
\text { ent }\end{array}$ & $\begin{array}{c}\text { Legitim } \\
\text { ate }\end{array}$ & $\begin{array}{c}\text { Rewa } \\
\text { rd }\end{array}$ & $\begin{array}{c}\text { Coerc } \\
\text { ive }\end{array}$ & $\begin{array}{c}\text { Expe } \\
\text { rt }\end{array}$ & $\begin{array}{c}\text { Refer } \\
\text { ent }\end{array}$ & $\begin{array}{c}\text { Legitim } \\
\text { ate }\end{array}$ & $\begin{array}{c}\text { Rewa } \\
\text { rd }\end{array}$ & $\begin{array}{c}\text { Coerc } \\
\text { ive }\end{array}$ & $\mathbf{n}$ \\
\hline \multicolumn{12}{|c|}{ Across-the-board } \\
\hline Strong & 6.04 & 5.75 & 6.19 & 5.92 & 5.50 & 5.94 & 5.89 & 5.75 & 5.62 & 5.10 & 58 \\
\hline $\begin{array}{l}\text { Moder } \\
\text { ate }\end{array}$ & 4.96 & 4.51 & 5.02 & 4.69 & 4.31 & 4.85 & 4.53 & 4.39 & 4.44 & 4.15 & $\begin{array}{c}10 \\
8\end{array}$ \\
\hline Weak & 4.30 & 3.79 & 4.38 & 3.98 & 3.63 & 4.20 & 3.82 & 3.61 & 3.63 & 3.20 & $\begin{array}{c}15 \\
3\end{array}$ \\
\hline \multicolumn{12}{|c|}{ Positive power } \\
\hline Strong & 5.97 & 6.07 & 5.47 & 5.19 & 2.18 & 5.77 & 5.69 & 4.91 & 4.82 & 2.23 & 32 \\
\hline
\end{tabular}

This article is protected by copyright. All rights reserved. 


\begin{tabular}{|c|c|c|c|c|c|c|c|c|c|c|c|}
\hline $\begin{array}{l}\text { Moder } \\
\text { ate }\end{array}$ & 5.57 & 4.69 & 5.38 & 3.77 & 2.05 & 5.06 & 3.96 & 2.72 & 2.14 & 1.61 & 91 \\
\hline Weak & 4.34 & 3.20 & 3.73 & 2.82 & 1.91 & 4.02 & 2.76 & 2.46 & 2.37 & 1.73 & 62 \\
\hline \multicolumn{12}{|c|}{$\underline{\text { Customer dominant }}$} \\
\hline $\begin{array}{l}\text { Moder } \\
\text { ate }\end{array}$ & 5.83 & 5.18 & 6.06 & 5.65 & 4.73 & 4.98 & 4.22 & 2.99 & 3.42 & 2.07 & 62 \\
\hline Weak & 4.85 & 3.90 & 5.09 & 4.33 & 4.06 & 3.71 & 2.56 & 1.97 & 2.07 & 1.73 & 51 \\
\hline \multirow[t]{2}{*}{$\mathrm{F}$} & $59.08^{*}$ & $64.26 * *$ & $65.57 * * *$ & $99.12 *$ & $112.11 *$ & $50.94 *$ & $99.39 * *$ & $122.43 * *$ & 161.92 & $154.96 *$ & \\
\hline & $* *$ & $*$ & & $* *$ & $* *$ & $* *$ & $*$ & $*$ & $* * *$ & $* *$ & \\
\hline
\end{tabular}

TABLE 7

Discriminant Analysis

\begin{tabular}{lcccc}
\hline Function & Eigenvalue & \% of Variance & Cumulative \% & Canonical Correlation \\
\hline 1 & 5.720 & 69.8 & 69.8 & $0.923^{* * *}$ \\
2 & 1.406 & 17.2 & 87.0 & $0.764^{* * * *}$ \\
3 & 0.772 & 9.4 & 96.4 & $0.660^{* * *}$ \\
4 & 0.250 & 3.0 & 99.4 & $0.447^{* * *}$ \\
5 & 0.028 & 0.3 & 99.8 & 0.166 \\
6 & 0.014 & 0.2 & 99.9 & 0.116 \\
7 & 0.004 & 0.1 & 100.0 & 0.064 \\
\hline${ }^{*}<0.05^{* *} \mathrm{p}<0.01$ & ${ }^{* * *} \mathrm{p}<0.001$ & & &
\end{tabular}

TABLE 8

Standardized Canonical Discriminant Function Coefficients

\begin{tabular}{lccccccc}
\hline & \multicolumn{7}{c}{ Function } \\
\cline { 2 - 8 } & $\mathbf{1}$ & $\mathbf{2}$ & $\mathbf{3}$ & $\mathbf{4}$ & $\mathbf{5}$ & $\mathbf{6}$ & $\mathbf{7}$ \\
\hline Customer power & & & & & & & \\
Expert & .156 & .313 & .076 & .164 & .684 & -.102 & .036
\end{tabular}

This article is protected by copyright. All rights reserved. 


$\begin{array}{llllllll}\text { Referent } & .237 & .292 & -.151 & -.068 & -.024 & -.443 & -.152 \\ \text { Legitimate } & .111 & .413 & .220 & .484 & -.304 & -.079 & .039 \\ \text { Reward } & .235 & .086 & .233 & -.442 & -.242 & -.141 & -.347 \\ \text { Coercive } & .317 & -.288 & .689 & -.040 & .162 & .249 & .467\end{array}$

Supplier power

$\begin{array}{lccccccc}\text { Expert } & .104 & .168 & -.110 & .190 & .208 & .593 & -.045 \\ \text { Referent } & .353 & .219 & -.166 & .003 & -.627 & .363 & .092 \\ \text { Legitimate } & .361 & -.169 & -.254 & .059 & .145 & -.453 & .753 \\ \text { Reward } & .316 & -.050 & -.220 & -.665 & .303 & .228 & -.270 \\ \text { Coercive } & .368 & -.408 & -.047 & .733 & -.079 & -.178 & -.501 \\ & & & & & & & \end{array}$

TABLE 9

Differences in Operational Performance

\begin{tabular}{|c|c|c|c|c|}
\hline \multirow[b]{2}{*}{ IPD } & \multirow{2}{*}{$\begin{array}{c}\text { Mean } \\
\text { Operational } \\
\text { Performance }\end{array}$} & \multicolumn{2}{|c|}{ Results of Hypothesis Tests } & \multirow{2}{*}{$\begin{array}{c}\text { Other } \\
\text { Significantly } \\
\text { Different IPDs }\end{array}$} \\
\hline & & Hypothesis & Supported? & \\
\hline $\begin{array}{l}\text { Strong across-the- } \\
\text { board (SATB) }\end{array}$ & 6.11 & $\begin{array}{l}\mathrm{H}_{1 \mathrm{a}}: \\
\mathrm{SATB}>\mathrm{MATB}, \text { WATB }\end{array}$ & Yes & WCD, WP \\
\hline $\begin{array}{l}\text { Moderate across- } \\
\text { the-board } \\
\text { (MATB) }\end{array}$ & 5.47 & $\mathrm{H}_{1 \mathrm{~b}}: \mathrm{MATB}>\mathrm{WATB}$ & Yes & SP, WP \\
\hline $\begin{array}{l}\text { Weak across-the- } \\
\text { board (WATB) }\end{array}$ & 4.87 & & & SP, MP, WCD \\
\hline $\begin{array}{l}\text { Strong } \\
\text { positive(SP) }\end{array}$ & 6.06 & $\mathrm{H}_{5 \mathrm{a}}: \mathrm{SP}>\mathrm{MP}, \mathrm{WP}$ & No & $\begin{array}{l}\text { WCD, MATB, } \\
\text { WATB }\end{array}$ \\
\hline $\begin{array}{l}\text { Moderate positive } \\
\text { (MP) }\end{array}$ & 5.84 & $\mathrm{H}_{5 \mathrm{~b}}: \mathrm{MP}>\mathrm{WP}$ & Yes & WCD, WATB \\
\hline
\end{tabular}

This article is protected by copyright. All rights reserved. 
(WP)

$\begin{array}{lllll}\begin{array}{l}\text { Moderate } \\ \text { customer }\end{array} & 5.83 & \mathrm{H}_{6 \mathrm{~b}}: \mathrm{MCD}>\mathrm{WCD} & \text { Yes } & \text { WP, WATB } \\ \text { dominant }(\mathrm{MCD}) & & & \end{array}$

Weak customer

5.04

dominant (WCD)

\section{OVERALL}

F

$24.70 * * *$
SP, MPC,

SATB, MATB

$* \mathrm{p}<.05, * * \mathrm{p}<.01, * * * \mathrm{p}<.00$

FIGURE 1

Conceptual Framework for Supply Chain Power

Dependence

$\underline{\text { Relationship Commitment }}$

Resources

Performance
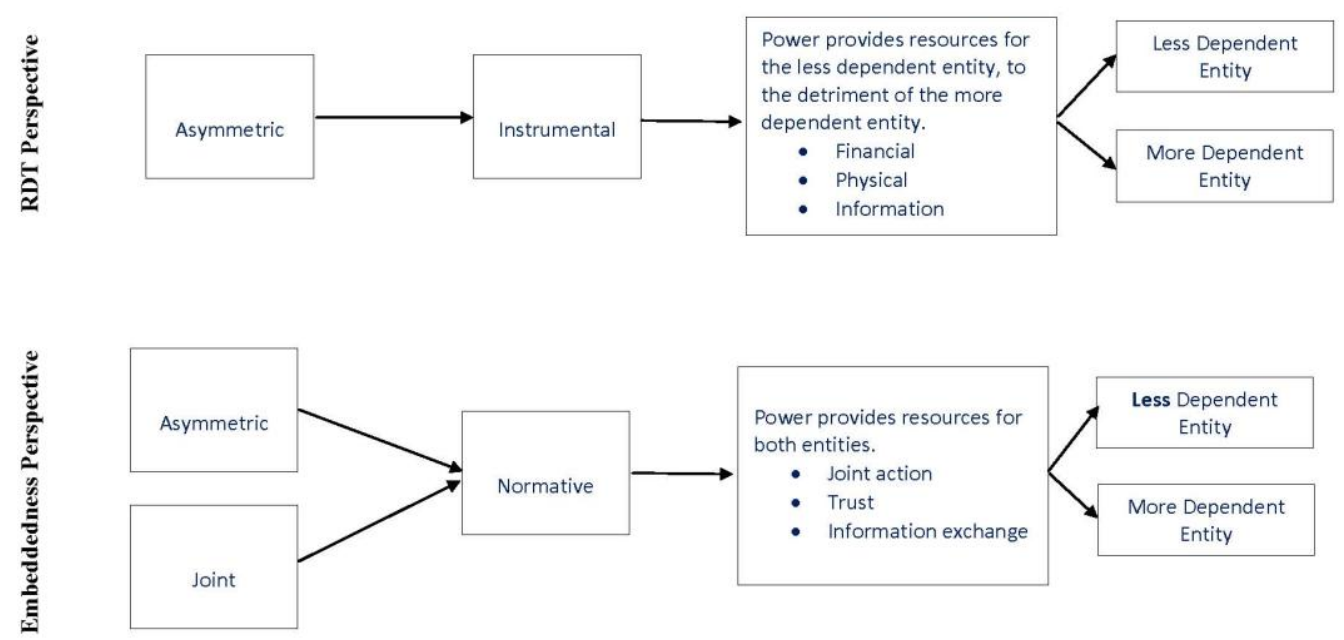

This article is protected by copyright. All rights reserved. 

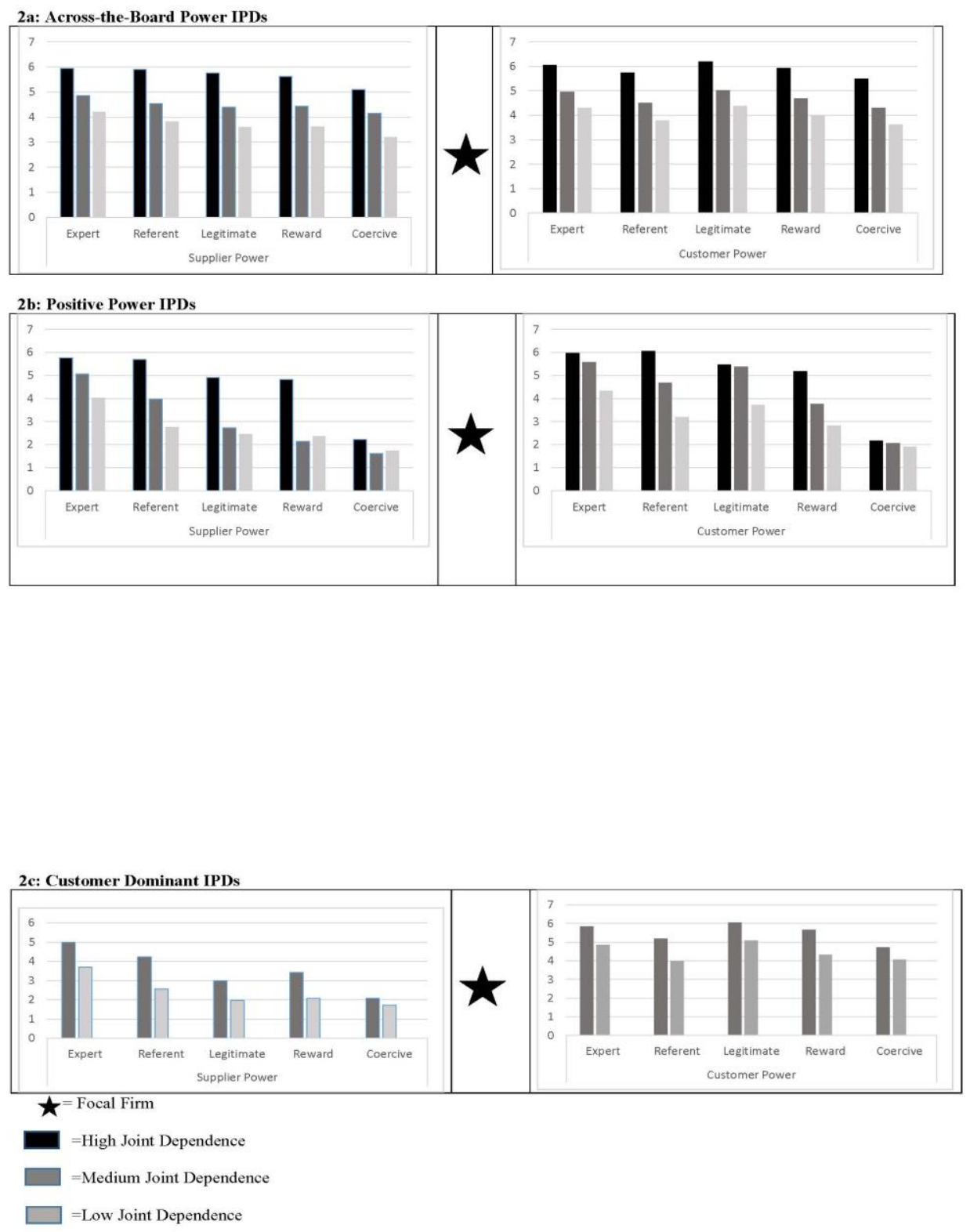

This article is protected by copyright. All rights reserved. 